\title{
BEHAVIOURAL RESPONSES OF AFRICAN CATFISH ( Clarias gariepinus BURCHELL, 1822) JUVENILES EXPOSED TO ACUTE CONCENTRATIONS OF BUTACHLOR (HERBICIDE)
}

\author{
"Salim, A. M., Dauda, A. B. and Yusuf, M. A. \\ Department of Fisheries and Aquaculture Federal University Dutsin-Ma. Katsina State, Nigeria. \\ *Corresponding authorsahmad@ fudutsinma.edu.ng;+2347039528683.
}

\begin{abstract}
This study examined the behavioral changes induced by butachlor to the juveniles of Clarias gariepinus. The experiment consists of five treatments $(0.6,0.7,0.8,0.9$ and $1.0 \mathrm{mg} / \mathrm{l})$ and a control. Ten fishes were allotted in each test tank in duplicates. Observations on behavioral responses were made at 0, 12, 24, 48, 72 and 96 hours post-exposure. The opercular movement and tail fin beat rates were observed as counts per minute using a stopwatch. The behavioral patterns of the fish in the control group were normal, whereas in the exposed groups the fish tend to lose equilibrium and swim erratically with vigorous jerky movements. At the $12^{\text {th }}$ and $24^{\text {th }}$ hours the fish in the exposed groups showed hyper-active movement; but became hypoactive at the $48^{\text {th }}$ hour. The mean values of the tail fin beat of the exposed groups were significantly higher $(\mathrm{p}<0.05)$ than that of the control at the $12^{\text {th }}$ hour. At the $24^{\text {th }}$ and $48^{\text {th }}$ hour post-exposure the exposed groups showed significant $(\mathrm{p}<0.05)$ time-dependent decrease compared to the control. The tail fin beat became significantly higher $(\mathrm{P}<0.05)$ in the control group from $72^{\text {nd }}$ hours onward. The decrease of tail fin beats at the $72^{\text {nd }}$ and $96^{\text {th }}$ hours were dose-dependent similar observations were also recorded in the opercular ventilation. At the $12^{\text {th }}$ hour the opercular ventilation of the exposed fish was significantly higher $(\mathrm{p}<0.05)$ than the control whereas at the $24^{\text {th }}$ and $48^{\text {th }}$ hours, the opercular ventilation of the exposed groups showed a significant decrease $(\mathrm{p}<0.05)$ compared to the control.
\end{abstract}

KEYWORDS: Butachlor, Herbicide, Acute, Behavioral, C.gariepinus

\section{INTRODUCTION}

The use of herbicides has been recognized as part of agricultural practices throughout the world. Unfortunately, the arbitrary use of these herbicides to enhance agricultural production and yield may have negative effects on non-target terrestrial and aquatic organisms (Nwani et al., 2010). Environmental pollution by herbicides has become a serious problem in terms of global conservation, animal and human health (Katsumata et al., 2005). According to Cerejeira et al. (2003) and Flynn and Spellman (2009), herbicides are ubiquitous agricultural chemicals that can proliferate regionally and globally into many ecosystems. Over the last few decades, the use of these chemicals has considerably increased about increasingly intensive agricultural practices.

Herbicides can accumulate in bodies of water to levels that kill zooplanktons and juvenile fishes and can also kill insects on which some fish feeds, thereby causing the fish to travel a distance in search of food and this expose them to greater risk from predators (Ikpesu, 2013). Herbicides, a distinctive group of pesticides, are considered as-selective chemical weed killers; hence they have been intensively used to destroy unwanted plants, especially in agricultural lands (Dutta and Meijer, 2003). The impact of herbicides is often greater than what is intended by those who use them, surface run-off into rivers and streams can be highly lethal to aquatic life. Herbicides reduce environmental quality and influence essential ecosystem functioning by reducing species diversity and modifying food chains (Alishahi et al., 2016). Aquatic bioassays are however necessary for water pollution control to determine whether a potential toxicant is dangerous to aquatic life (Olaifa et al., 2003). The increasingly widespread use of herbicides in agriculture and their impact on non-target aquatic organisms require specific studies on their effects on economically significant species such as the African catfish (Clarias gariepinus). Fish can serve as bioindicators of environmental pollution and therefore can be used for the assessment of the quality of the aquatic environment (Lopes et al., 2001) since they are directly exposed to chemicals resulting from agricultural production via surface runoff of water or indirectly through the food chain of the ecosystem (Ateeq et al., 2002). The present study is aimed at studying the behavioural alterations caused by butachlor to juveniles of $C$. gariepinus.

\section{MATERIALS AND METHOD \\ Preparation of Test Solution}

A commercially available herbicide Butatex ${ }^{\circledR}$ with Butachlor as an active ingredient was used for the study. The herbicide was purchased from an agrochemical shop in Sabon-Gari market, Zaria. The stock of the test chemical was prepared by dissolving $1 \mathrm{mg}$ of Butachlor in 1 litre of test water in a conical flask following the procedures of Dede and Kagbo (2001).

A range finding test was carried out to check for the concentration of the herbicide that was used for the definitive tests. This was done by placing five nominal concentrations $(0.5,1.0,1.5,2.0$ and $2.5 \mathrm{mg} / \mathrm{l})$ of the herbicide in separate tanks and ten fishes were stocked in each tank, mortality of the stocked fish was observed at $0,12,24,48,72$, and 96 hours. The concentrations were graded using lower ranges until $80-90 \%$ mortality was recorded in the highest concentration and 20-30\% for the lowest concentration as suggested by Martins et al. (2008).

\section{Acute Toxicity Test}

A four-day static toxicity bioassay was conducted in the hFisheries Laboratory of the Department of Biological Sciences Ahmadu Bello University, Zaria, using juveniles of $C$. 
gariepinus. The experiment was a completely randomized design with five treatments and a control in duplicates, $(0.0,0.6$, $0.7,0.8,0.9$ and $1.0 \mathrm{mg} / \mathrm{l})$. Butachlor was added to each glass tank $(30 \mathrm{~cm} \times 30 \mathrm{~cm}$ x $45 \mathrm{~cm})$ containing 201 of de-chlorinated tap water. The addition was done for varying concentrations using a syringe and allowed to stand for 10 minutes for the toxicant to be evenly distributed. Ten fishes were allotted to each tank.

Observations of the behavioral responses were made at 0,12 , $24,48,72$ and 96 hours post-exposure. The opercular movement and tail fin beat rates were observed as counts per minute using a stopwatch. The opercular movement and tail fin movement were counted for three fishes in each tank and the mean recorded. (OECD 1992).

\section{RESULTS}

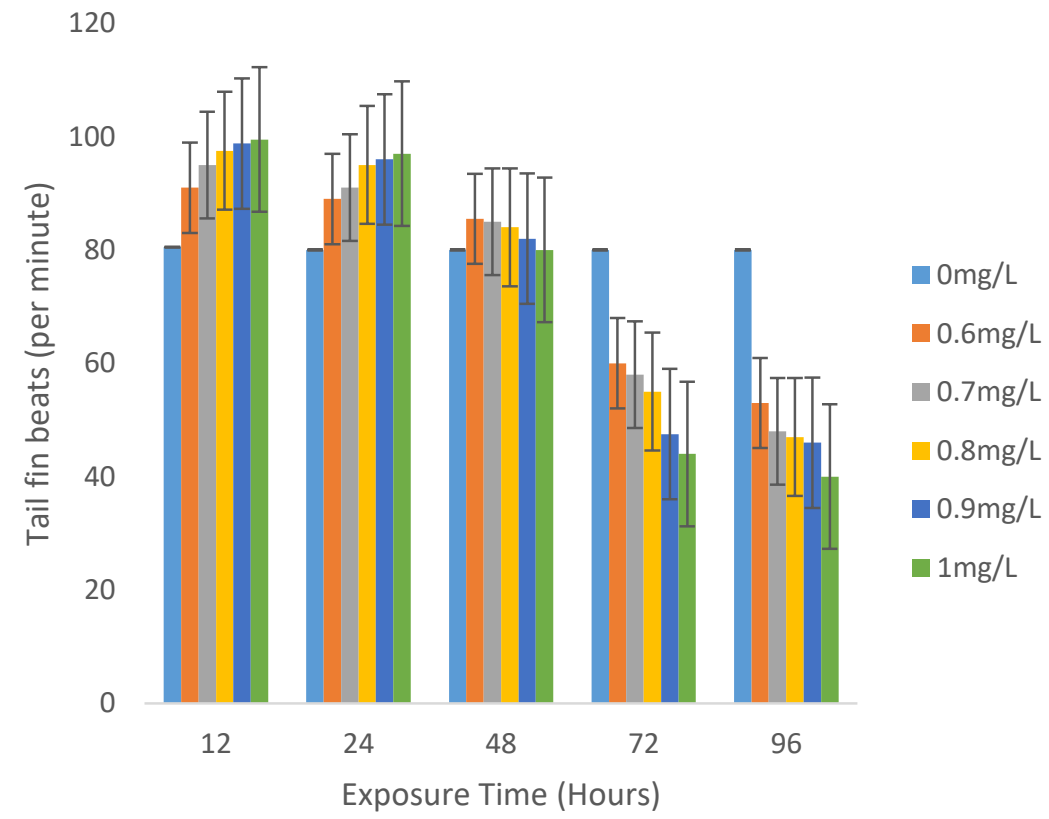

Figure 1: Tail fin beats (per minute) of C. gariepinus juveniles exposed to acute concentrations of Butachlor. 


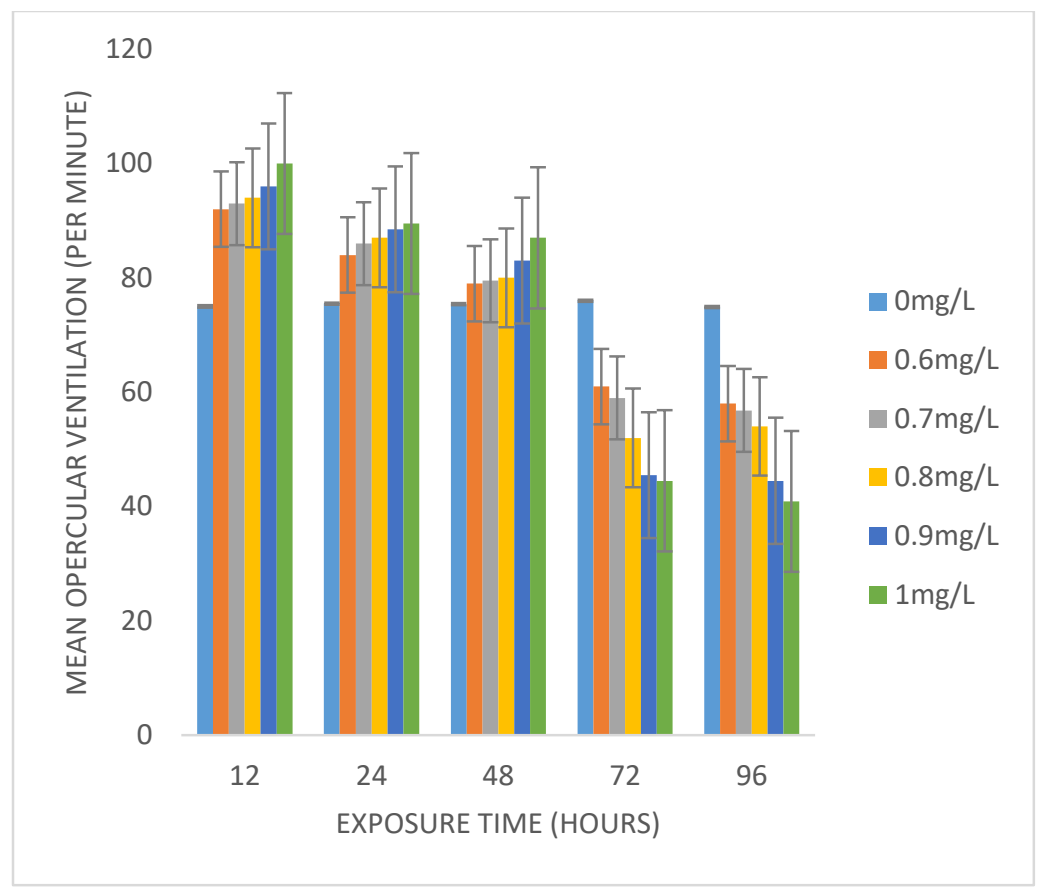

Figure 2: Opercular ventilation (per minute) of $C$. gariepinus juveniles exposed to acute concentrations of Butachlor.

\section{DISCUSSION}

Fish exposed to different concentrations of the herbicide displayed behavioural abnormalities in response to the herbicide. At the early exposure, fish stop swimming and remain stationary, this might be in response to the sudden change in the water medium, after some time the swimming of the fish in the exposed groups became erratic with vigorous jerky movements, hyperactivity, faster opercular and tail fin movement restlessness and gulping of air. Hyperactivity of fish in the exposed group could be attributed to an attempt to evade the test water (toxic environment). El- Sharkawy et al. (2011) reported that jumping to the water surface to gulp air by fish could be attributed to either oxygen depletion as a result of pollution caused by herbicides or other toxic chemicals present in the water or irritation caused by dermal contact and subsequently this irritates the gills. Mekkawy et al. (2013) also reported hyperactivity in $C$. gariepinus exposed to atrazine which was characterized by rapid and erratic swimming darting, partial loss of equilibrium, rapid pectoral fin and opercular movement, reduction in feeding activity and fin haemorrhage.

The behavioural and swimming patterns of the fish in the control group in the present study were normal but for the exposed groups abnormal swimming behaviour increased with an increase in the toxicant concentration. Similar observations were made by Ayoola (2008). Kumar et al. (2010), Bekeh et al. (2011), Banaee et al. (2011), Chang et al. (2011), Pandey et al., (2011), Altinok et al. (2012) and Nwani et al. (2013).

The early increase in opercular ventilation count in the exposed groups may be an attempt by the fish to suppress the effect of the toxicant by breathing faster. The increase in opercular ventilation rate may also be linked with the sudden response of the fish to the shock of exposure to the toxicant (Chindah et al., 2004). This hyperventilation probably an attempt by the fish to cope with the environment at the initial period but with the increase in exposure time, the fish become weak and finally die due to suffocation. The increase might also be attributed to an increase in oxygen demand needed for the increased metabolic activities. This finding is comparable to that of Nwani et al. (2013) who reported faster opercular movements in $C$. gariepinus exposed to termifos. Obiezue et al. (2014) also noted rapid opercular movement in diethyl exposed $C$. gariepinus. The authors affirmed that this as well as other abnormal behaviours observed suggested nervous disorder. Similar findings were also reported by Auta et al. (2000) and Bayero (2017). Physiologically, fish reacts to toxicants by increasing rate of respiration in an attempt to pass more water and invariably oxygen over the surface of the gills. However, the fish ends up passing more toxicant over the gills, and a decline in opercular ventilation counts with increase in the exposure period. The decline in opercular ventilation count observed in this study may be credited to a decrease in respiratory rates and suggested decreased oxygen consumption because the fish has become exhausted due to several attempts to escape from the toxic medium or frequently surfacing to facilitate oxygen intake. Auta et al. (2002) and (2005) reported a decrease in opercular ventilation count with increased exposure time. In contrast, Yaji (2012) observed an increase in the opercular ventilation count of Oreochromis niloticus exposed to acute concentrations of cypermethrin in the static assay at the 96th hour.

The initial increase in the tail beat frequency of fish in exposed groups observed in the present study can be linked to increased metabolic activity by the fish to swim faster and escape the polluted environment. However, as exposure time increases the tail fin beats decrease Ufodike and Omoregie (1990) reported that, increase in opercular ventilation and tail fin beats within initial periods of toxicant exposure act as an avoidance syndrome exhibited by fish. However, as this effort became 
ineffective, fish became weak and a decline was observed in the tail fin beat frequency with an increase in exposure time. Tail fin movement is a mechanical activity and requires the use of energy. This decline in tail fin movement rates can be attributed to disorder in energy synthesis possibly through blockage of the electron transport chain. Similar findings were reported by Chindah et al. (2004), Ogundele et al. (2004) and Onuoha and Ohaturonye, (2007). However, Yaji (2012) reported a different finding in $O$. niloticus exposed to cypermethrin for 96 hours in both static and flow-through experiments; the author recorded an increased tail movement rate in the 96th hour of exposure.

\section{CONCLUSION}

It is obvious from the findings that tachlor imposed behavioral changes in Clarias gariepinus juveniles, which might have caused by the sudden change in the water environment. The sudden change caused the fish to move faster to escape the toxic environment.

\section{REFERENCES}

Alishahi, M., Tulaby Dezfuly, Z., and Mohammadian, T. (2016) Acute toxicity evaluation of five herbicides: paraquat, 2,4-dichlorophenoxy acetic acid (2,4-D), trifluralin, glyphosite and atrazine in Luciobarbus esocinus fingerlings Iranian Journal of Veterinary Medicine, 10 (4):319-330.

Altinok, I., Capkin, E. and Boran, H. (2012). Mutagenic, Genotoxic and Inhibitory Effects of Carbosulfan in Rainbow Trout Oncorhynchus Mykiss. Pesticide Biochemistry and Physiology, 102:61-67.

Ateeq, B., Abul-farah, M., Niamat Ali, M. and Ahmad, W. (2002). Induction of Micronuclei and Erythrocyte Alterations in the Catfish Clarias batrachus by 2,4- dichlorophenoxyacetic acid and butachlor, Mutation Research, 518, 135-44.

Auta, J., Akande, G.A., Balogun, J.K., Oniye, S.J. and Balarabe, M.L. (2000). Acute Toxicity of Cypemethrin to a Freshwater Fish Oreochromis niloticus. A Paper Presented At the 15th Annual Conferences of the Fisheries Society of Nigeria (FISON), 19th-20th March 2000; Jos, Plateau State.

Auta, J., Yaji, J. A. and Onwude, U. M. (2005). Acute toxicity of endosulphan to the freshwater fish (Oreochromis niloticus). 20th Annual Conference of the Fisheries Society of Nigeria (FISON), Port Harcourt, 73p.

Ayoola, S.O. (2008). Toxicity of Glyphosate Herbicide on Nile Tilapia (Oreochromis niloticus) Juvenile. African Journal of Agricultural Research, 12:825-34.

Banaee, M., Sureda, A., Mirvaghefi, A.R. and Ahmadi, K. (2011). Effects of Diazinon on Biochemical Parameters of Blood in Rainbow Trout (Oncorhynchus mykiss). Pesticides Biochemistry and. Physiology. 99:1-6.

Bayero, U. (2017). Toxicity of Atrazine (herbicide) to Juveniles of the African catfish, clarias gariepinus (bürchell, 1822). Ahmadu Bello University Zaria Unpublished M.Sc. Thesis $126 \mathrm{p}$.

Bekeh, A.F., Ndome, C.B. and Bayin, P.R.B. (2011). Some Hematological Changes In Oreochromis Niloticus Juveniles
Exposed To Butachlor. Journal of Agriculture and Food Technology, 1 (6):73-80.

Cerejeira, M. J., Viana, P., Batista, S., Pereira, T., Silva, E. and Valerio, M. J. (2003).Pesticides In Portuguese Surface and Ground Waters. Water Research, 37: 1055-1063.

Chang, J., Liu, S., Zhou, S., Wang. M. and Zhu, G. (2011). Effects of butachlor on reproduction and hormone levels in adult zebrafish (Danio rerio). Experimental Toxicology and Pathology, doi:10.1016/j.etp.2011.08.007.

Chindah, A.C., Sikoki, F.D. and Vincent-Akpu, I. (2004). Toxicity of organophosphate pesticide (chloropyrifos) on common Niger Delta wetland fish- Tilapia guineensis (Bleck 1862). Journal of Applied Science and Environmental Management, 8(2):11-17.

Dede, E.B. and Kagbo, H.D (2001). Aqua-toxicological Effects of Water Soluble Fraction (WSF) of Diesel Fuel on Oreochromis niloticus Fingerlings. Journal of Applied Science and Environmental Management, 5:93-96.

Drummond, R.A., Russom, C.L. and Gleger, D.L. (1986). Behavioral And Morphological Changes In Fathead Minor (Pimphales Promelas) As Diagnostic End Points For Screening Chemicals According To Mode Of Action; In T.M. Poston And R.Pruddy (Eds). Aquatic Toxicology and Environment Fate, Vol. 9, Philadelphia. Pp 415-435.

Dutta, H. M. and Meijer, H. J. M. (2003).Sublethal Effects of Diazinon on The Structure of the Testis of Bluegill, Lepomis macrochirus: A Microscopic Analysis. Environmental Pollution, 725(3): 355-360.

El-Sharkawy, N.I., Rasha M., Reda. and El-Araby E.I. (2011) Assessment of Stomp ${ }^{\circledR}$ (Pendimethalin) toxicity on Oreochromis niloticus Journal of American Science, 7(10):568576.

Flynn, K. and Spellman, T. (2009). Environmental levels of atrazine decrease spatial aggregation in the freshwater mussel, Elliptio complanata. Ecotoxicology and Environmental Safety, 72: $1228-1233$.

Ikpesu T.O (2013). Recovery Mechanism in Fishes With Reference to Recuperation of Haemathological Parameters in Clarias gariepinus Aberrated by Herbicide Paraquat dichloride Bulletin of Pharmaceutical and Medical Sciences, (BOPAMS) Vol.1: 2-5

Katsumata, H., Fujii, A., Kaneco, S., Suzuki, T. and Ohta, K. (2005). Determination of Simazine in Water Samples by HPLC after Pre-concentration with Diatomaceous earth. Talanta, 65: $129-134$.

Kumar, R., Nagpure, N.S., Kushwaha, B., Srivastava, S.K. and Lakra W.S (2010). Investigation of the genotoxicity of malathion to freshwater teleost fish Channa punctatus (Bloch) using the micronucleus test and comet assay. Archives of Environmental Contamination and Toxicology, 58:123-130.

Lopes, P. A., Pinheiro, T., Santos, M. C., Da Luz Mathias, M.S., Collares-Pereira, M. J., Viegas and Crespo, A. M (2001).Response of Antioxidant Enzymes in Freshwater Fish Populations (Leuciscus alburnoides complex) to Inorganic Pollutants Exposure. Science Total Environment, 280, 153-63. 
Martins, M. L., Mouriño, J. L.P., Amaral, G. V., Vieira, F. N., Dotta, G., Jatoba, A. M. B., Pedrotti F. S., Jerônimo, G. T., Buglione-Neto, C. C. and Periera -Jr, G. (2008). Haemathological Changes in Nile Tilapia Experimentally Infested with Enterococcus species. Brazil Journal of Biology, 68(3):657-661.

Mekkawy, I. A. A., Mahmoud, U. M. and Mohammed, R. H. (2013). Protective Effects of Tomato Paste and Vitamin E on atrazine-induced Hematological and Biochemical Characteristics of Clarias gariepinus (Bürchell, 1822). Global Advanced Research Journal of Environmental Science and Toxicology, 2(1): 11-21 (ISSN: 2315-5140) Available online http://garj.org/garjest/index.htm.

Nwani, C. D., Nagpure, N. S., Kumar, R., Kushwaha, B., Kumar, P. and Lakra, W. S. (2010). Lethal concentration and toxicity stress of Carbosulfan, Glyphosate and Atrazine to freshwater air breathing fish Channapunctatus(Bloch). International Aquatic Research, 2: 105-11. ISSN 2008-4935 Available online at www.intelaquares.com

Nwani, C.D., Udu -Ibiam A., Florence O., Uche O. O., Rebecca C. O., Arua A. I. and Onyinyechi U. (2013). Acute Toxicity of the Chloroacetanilide Herbicide Butachlor and its Effects on the Behavior of the Freshwater Fish Tilapia zillii. African Journal of Biotechnology, 12(5), pp. 499-503

Obiezue, R.N., Ikele, C.B., Mgbenka, B.O., Okoye, I.C., Attamah, G.N., Uchendu, C., Ezeamachi, E. and Onyia, C.Q., (2014) Toxicity Study of Diethyl phthalate on Clarias gariepinus Fngerlings, African Journal of Biotechnology, 13 (7) 884-896.

OECD Guidelines for Testing of Chemicals (No.203; Adopted: 17th July, 1992): Fish, Acute Toxicity Test (www.oecd.org/dataoecd/17/20/1948241.pdf).

Ogundele, O., Ihuahi, J.A., Omojowo, F.S and Bitrus, P. (2004). Toxicity of Linear Alkylbenzene Sulphonate (LAS) Detergent to Clarias gariepinus Fingerlings. Proceedings of the 19th Annual Conference of the Fish. Society of Nigeria (FISON), 273-276pp.
Olaifa F.E, Olaifa, A.K, and Lewis O.O. (2003). Toxic Stress of Lead on Clarias gariepinus (African catfish) Fingerlings. African Journal of Biomedical Research, 6, $101-104$.

Onuoha, G. C., and Ohaturonye, S. (2007). Haematological parameters of Oreochromis niloticus on treatment with crude cassava (Crantz) stain TMS 30572 leaf extract. Nigerian Journal of Fisheries, 4(2): 114-123.

Pandey, A.K., Nagpure, N.S., Trivedi, S.P., Ravindra, K., Kushwaha, B. and Lakra, W.S. (2011). Investigation on Acute Toxicity and Behavioral Changes in Channa punctatus (Bloch) due to Organophoshate Pesticide Profenofos. Drug and Chemical Toxicology, 34 (4):424-428.

Ufodike, E. B. C. and Omoregie, E. (1990). Acute toxicity of gammalin 20 and acetellic $25 \mathrm{EC}$ to Oreochromis niloticus. Acta Hydrobiologia, 32: 445-447.

Yaji, J.A. (2012). Toxicity of Cypermethrin and Propanil (Pesticides) on Juveniles of Tilapia (Oreochromis niloticus Trewavas). Ph.D thesis Department of Biological Sciences Ahmadu Bello University, Zaria. 168-170pp.

(C)2021 This is an Open Access article distributed under the terms of the Creative Commons Attribution 4.0 International license viewed via https://creativecommons.org/licenses/by/4.0/ which permits unrestricted use, distribution, and reproduction in any medium, provided the original work is cited appropriately. 